\title{
Weeds of Wheat Crop and Their Control Strategies in Dera Ismail Khan District, Khyber Pakhtun Khwa, Pakistan
}

\author{
Sarfaraz Khan Marwat ${ }^{1 *}$, Khalid Usman², Niamatullah Khan², Muhammad Umar Khan², \\ Ejaz Ahmad Khan', Muhammad Anwar Khan ${ }^{2}$, Aziz Ur Rehman ${ }^{2}$ \\ ${ }^{1}$ University WENSAM College, Gomal University, Dera Ismail Khan, Pakistan; ${ }^{2}$ Department of Agronomy, Faculty of Agriculture, \\ Gomal University, Dera Ismail Khan, Pakistan; ${ }^{3}$ Department of Agriculture Chemistry, Faculty of Agriculture, Gomal University, \\ Dera Ismail Khan, Pakistan. \\ Email: "skhan.marwat@gmail.com
}

Received August $9^{\text {th }}, 2012$; revised September 15 ${ }^{\text {th }}, 2012$; accepted September $27^{\text {th }}, 2012$

\begin{abstract}
This study is based on research work conducted during 2008-2010 in Dera Ismail Khan, KPK, Pakistan. The research area was extensively surveyed to investigate weed species. About 32 weed species, belonging to two monocot and thirteen dicot families, were collected from the study area. Plants were identified with the help of available literature and by comparing with the already identified plant specimens of the herbarium of Quaid-i-Azam University, Islamabad, Pakistan. Data inventory constitutes botanical name, vernacular name, English name, family, and flowering and fruiting period. Phalarus minor, Rumax dentatus, and Chenopodium album were the dominant weeds in the study area having comparatively higher relative weed density. Weeds having tough competition with wheat crop for light, moisture, and nutrients adversely affect wheat production. Hence, a constant effort is needed to keep the weed population under control. Many methods of weed control and eradication have been devised but chemical control is the most effective one. However, it may have some environmental consequences if not handled properly.
\end{abstract}

Keywords: Weeds; Control Strategies; Wheat Crop

\section{Introduction}

Weeds are unwanted plant species growing in the domesticated crops [1]. They in simpler terms are plants that interfere with the healthy or normal growth and development of crops. They are now known to limit the production of crops causing serious losses in the output of grains, seeds and fruits etc. [2].

The concept of weeds as unwanted plant was born when man started to grow plants deliberately for food and other purposes [1]. Weeds belong to all plant families, but certain families particularly Asteraceae, Poaceae, Brassicaceae and Fabaceae constitute the worldwide major weed flora [3].

There are about 30,000 species of weeds in the world, of which 50 to 200 usually cause appreciable damage to the major food crops [4]. Holm, et al. (1979) estimated 250 weed species which are common in agricultural crops throughout the world [1].

Heavy weeds infestation may cause complete crop failure. The cost of removing weeds adds to the cost of

${ }^{*}$ Corresponding author. production of crops, thus producers losses part of their investment and the country suffers a reduction in agricultural products. They harm our agricultural crops in other ways as well. They harbour insect pests and plant diseases and on account of their rapid regenerative powers they pose serious problems in our daily life in maintaining our gardens, lawns, roads and water channels [2]. Decrease in the yield of crops due to weed infestation has been well documented [5].

In Pakistan the percentage losses in yield due to unchecked weed growth in different crops are significant. In some of the crops the yield may be reduced by more than $50 \%$ [4]. It is estimated that in wheat yield losses range from $20 \%$ to $40 \%$ due to weeds [6]. Losses in wheat yield due to weeds amount to more than Rs. 28 billion at national level and Rs. 2 billion at provincial level in NWFP [7].

The critical weed competition period in wheat is 30 to 60 days after sowing. After 60 days of sowing there is no economic benefit to eradicate weeds from wheat crop [6].

Wheat (Triticum aestivum L.) is an important cereal crop. It is a dietary mainstay for approximately one-third 
of the total world population. Being staple food wheat plays an important role in the economy of Pakistan, hence occupies a central position in agricultural policy making. It produces several tillers plant $^{-1}$ depending upon soil fertility crowding and environmental conditions. Wheat supplies about $73 \%$ of the calories and protein of the average diet [8].

Several studies on weeds of wheat crop have been recorded from various parts of Pakistan i.e., Dir [9], Tando Jam, Sindh [6], Chitral [5], Malakandar farm, Peshawar [8], Khairpur [10], Toba Tek Singh [11], Swat [12] and

\section{Toba Tek Singh [13].}

The Present paper reports the distribution of weed species within Dera Ismail Khan District and will be helpful for recognizing the severity of weed infestation in wheat crop and weed competition in the area.

\section{Materials and Methods}

The research work was conducted during 2008-2010 in Dera Ismail Khan District, which is located in Khyber Pakhtunkhwa (KPK), Pakistan (Figure 1) and has an

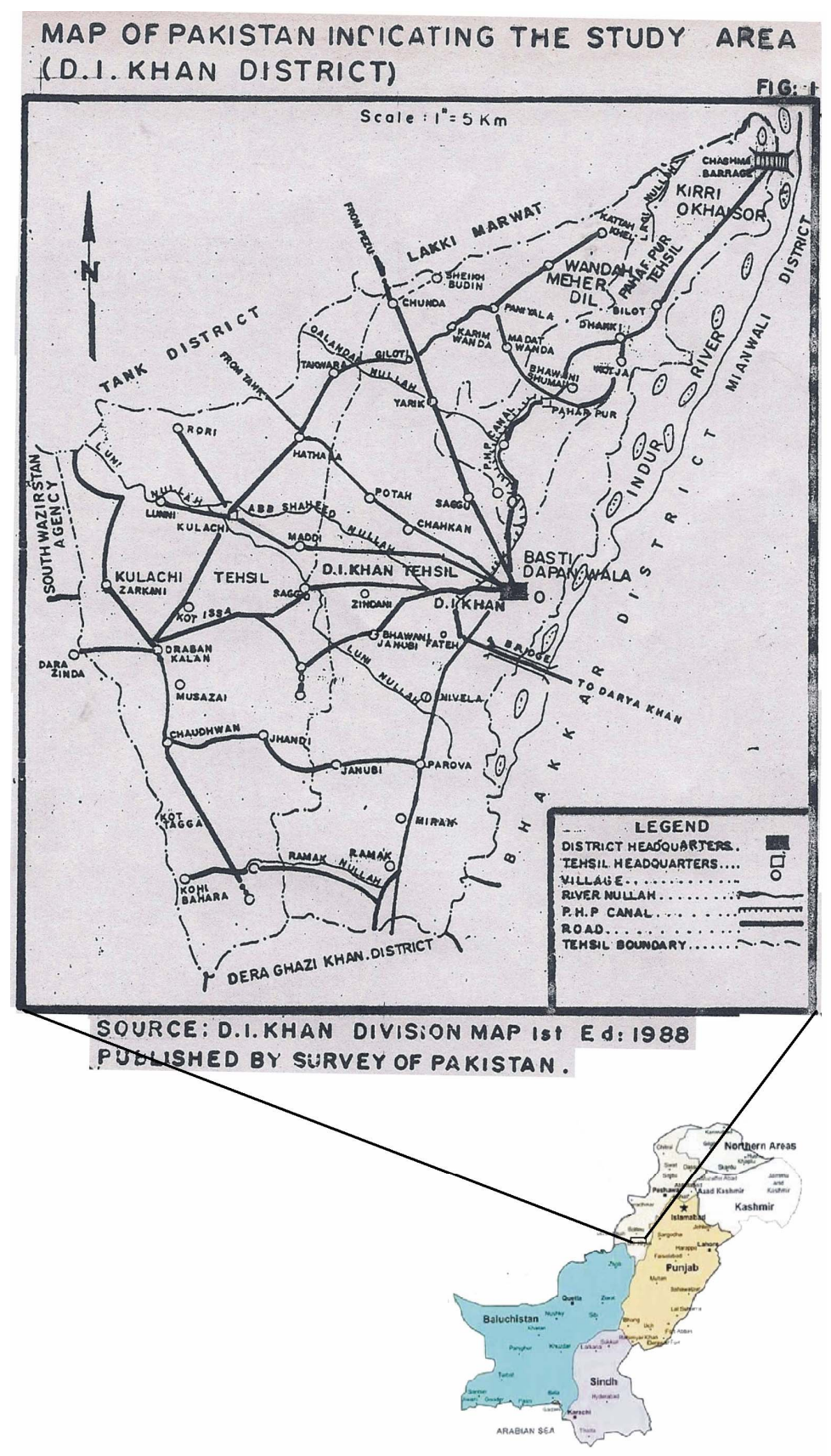

Figure 1. Map of Dera Ismail Khan, KPK, Pakistan. 
elevation of 173 meters above sea level. It has a total geographical land mass of 0.896 million hectares out of which $33 \%$ is cultivated [14]. The climate is arid to semi arid with average annual rainfall of 180 to $200 \mathrm{~mm}$. The mean maximum and minimum temperatures during winter are $20.3^{\circ} \mathrm{C}$ and $4.2^{\circ} \mathrm{C}$ respectively, compared to $42^{\circ} \mathrm{C}$ and $27^{\circ} \mathrm{C}$ during summer [15]. Frequent field trips were arranged to various parts of the area to collect weed species in wheat crop. Data on weed density $\mathrm{m}^{-2}$ was recorded by placing square quadrate at different locations (Gomal University, Ratta Kulachi, Pahar Pur) in the farmers' fields. Relative weed density (\%) or species wise weed density was then calculated by a formula [Relative weed density $(\%)=($ Number of weeds of a species/total number of weeds) $\times 100]$. Data was statistically analyzed using analysis of variance techniques appropriate for randomized complete block design [16]. When $F$-values were significant, means were compared using the least significant difference (LSD) test at 0.05 level of probability. The dominant weeds were particularly focused for correct identification and their control strategy. A questionnaire was also developed to interview the farmers as how they control the prevailing weeds in their area. All the traditional and improved methods of weed control were reported from the study area. Farmers and Agriculture extension workers were also interviewed for the most effective weed management strategy. Plants collected from the study areas were then identified with the help of available literature [1719] and by comparing with the already identified plant specimens of the herbarium, Quaid-i-Azam University, Islamabad. After correct identification, the plants were deposited in the herbarium of the said university. Plants with botanical name, vernacular name, English name, family, flowering and fruiting period, major diagnostic characters and $\%$ age share of families were listed in Tables 1-3. Photographs of some important weeds have been presented in Figures 2(a)-(l).

Table 1. Weeds of wheat crop in D. I. Khan district, KPK, Pakistan.

\begin{tabular}{|c|c|c|c|c|}
\hline S.\# & Scientific name & Family & English name & Vernacular name \\
\hline 1. & Amaranthus viridis $\mathrm{L}$. & Amaranthaceae & Pigweed & Jangli cholai \\
\hline 2. & Anagallis arvensis $\mathrm{L}$. & Primulaceae & Blue Pimpernel & Billi booti \\
\hline 3. & Asphodelus tenuifolius Cav. & Asphodeliaceae & Wild onion & Piazi, bhokat \\
\hline 4. & Avena fetua $\mathrm{L}$. & Poaceae & Wild oat & Jangli jai, Javdri \\
\hline 5. & Carthamus oxycantha (L.) G. Don & Asteraceae & Wild safflower & Pohli, kandiari \\
\hline 6. & Chenopodium album L. & Chenopodiaceae & Goose foot & Bathu,bathwa \\
\hline 7. & Chenopodium murale L. & Chenopodiaceae & Fat hen & Karund \\
\hline 8. & Cichorium intybus L. & Asteraceae & Blue daisy & Kasni \\
\hline 9. & Cirsium arvense (L.) Scop & Asteraceae & Creeping thistle & Kandyari, Leh \\
\hline 10. & Convolvulus arvensis L. & Convolvulaceae & Field binweed & Lehli, Hirankhuri \\
\hline 11. & Coronopus didymus (L.)Smith. & Brassicaceae & Swine cress & Jangli halon \\
\hline 12. & Cynodon dactylon (L.) & Poaceae & Bermuda Grass & Dub, Khabbal \\
\hline 13. & Euphorbia helioscopia L. & Euphorbiaceae & Sun spurge & Dudhi \\
\hline 14. & Fumaria indica (Hausskn) Pugsley & Fumariaceae & Fumitory & Shahtra, pitpapra \\
\hline 15. & Galium aparine L. & Rubiaceae & Bedstraw & Warribooti \\
\hline 16. & Lathyrus aphaca L. & Papiolanaceae & Crow pea & Dokanni \\
\hline 17. & Lathyrus sativus L. & Papiolanaceae & Grass pea & Chraal, kasseri \\
\hline 18. & Lepidium sativum L. & Brassicaceae & Garden cress & Halon \\
\hline 19. & Malva parviflora $\mathrm{L}$. & SMalvaceae al & Dwarf mallow & Sonchal \\
\hline 20. & Medicago polymorpha L. & Papiolanaceae & Bur clover & Maina \\
\hline 21. & Melilotus alba Desr. & Papiolanaceae & White sweet clover & Sufaid senji \\
\hline 22. & Melilotus indica (L.) All. & Papiolanaceae & Yellow sweet clover & Zard senji \\
\hline 23. & Phalaris minor Retz. & Poaceae & Bird's seed grass & Dumbi sittee \\
\hline 24. & Polygonum plebejum R. Br. & Polygonaceae & Prostrate knotweed & Dranak, hazardani \\
\hline 25. & Polypogon monspeliensis (L.) Desf. & Poaceae & Rabbit foot grass & Lomar ghas \\
\hline 26. & Rumex dentatus L. & Polygonaceae & Broadleaf dock & Jangli palak \\
\hline 27. & Saponaria vaccaria $\mathrm{L}$. & Caryophyllaceae & Soapwort & Takla \\
\hline 28. & Sisymbrio irio L. & Brassicaceae & London rocket & Khoob kalan \\
\hline 29. & Sonchus asper (L.) Hill & Asteraceae & Spiny sowthisle & Kandiali, dodhak \\
\hline 30. & Spergula arvensis L. & Spergulaceae & Corn spurry & Kalri booti \\
\hline 31. & Stelleria media (L.) Vill. & Caryophyllaceae & Common chickweed & Stel Phullan booti, \\
\hline 32. & Vicia sativa $\mathrm{L}$. & Papiolanaceae & Common vetch & Revari, Choti phali \\
\hline
\end{tabular}


Table 2. Major diagnostic characters of weeds of wheat crop in D. I. Khan district.

\begin{tabular}{|c|c|c|c|c|}
\hline Scientific name & Fl. \& Fr. & Group & Life cycle & Major diagnostic characters \\
\hline Amaranthus viridus & Aug-Nov & Dicot & Annual & $\begin{array}{l}\text { An erect or more rarely ascending herb; inflorescence } \\
\text { paniculate spikes, terminal; flowers green. }\end{array}$ \\
\hline Anagallis arvensis & Mar-Apr & Dicot & Annual & $\begin{array}{l}\text { Prostrate or decumbent herb, square in outline; leaves } \\
\text { sessile, opposite and decussate; flowers solitary, axillary, red } \\
\text { or blue; capsule with dark brown angular seeds. }\end{array}$ \\
\hline Asphodelus tenuifolius & Nov-Apr & Monocot & Annual & $\begin{array}{l}\text { An erect herb; leaves linear, fistular, sheathing at the base; } \\
\text { flowers laxly racemose; perianth white to pale pink; capsule } \\
\text { globose; seeds trigonous, black. }\end{array}$ \\
\hline Avena fatua & Mar-Apr & Monocot & Annual & $\begin{array}{l}\text { A tufted, erect to geniculate herb; Spikelets usually 3- rarely } \\
\text { 2- or 4-flowered; lemma back has long, stiff hairs and a } \\
\text { geniculate and twisted dorsal awn; fruit straw coloured; } \\
\text { seeds hairy or tufted }\end{array}$ \\
\hline Carthamus oxycantha. & Sept-Nov & Dicot & Annual & $\begin{array}{c}\text { A spiny-leaved herb; infl. Terminal racemose with yellow } \\
\text { flowers; seeds shining grey coloured or black spotted, } \\
\text { pappus lacking. }\end{array}$ \\
\hline Chenopodium album & Apr-Jun & Dicot & Annual & $\begin{array}{l}\text { An erect or suberect herb, more or less mealy; leaves } \\
\text { varing from rhombic-ovate to lanceolate; infl. } \\
\text { panicled spikes often mealy. }\end{array}$ \\
\hline Chenopodium murale & May-Oct & Dicot & Annual & $\begin{array}{l}\text { An erect, angular, slightly mealy herb; leaves, } \\
\text { rhombic-ovate, dark green, irregularly toothed; inflorescence } \\
\text { terminal and axillary, loosely branched cymes. }\end{array}$ \\
\hline Cichorium intybus & Jun-Sept & Dicot & Annual & $\begin{array}{c}\text { An erect, grooved, herbaceous; infl. Terminal or axillary } \\
\text { capitulum with blue flowers. }\end{array}$ \\
\hline Cirsium arvense & Jan-Mar & Dicot & Perennial & $\begin{array}{c}\text { An erect herb; stem branched, slightly hairy; leaves } \\
\text { lance-shaped, lobed with spiny margins; infl. head } \\
\text { rose-purple or white. }\end{array}$ \\
\hline Convolvulus arvensis & Apr-Sept & Dicot & $\begin{array}{l}\text { Annual or } \\
\text { Perennial }\end{array}$ & $\begin{array}{l}\text { D Diffuse or procumbent; basal and lower leaves rosulate, } \\
\text { pinnatisect, stalked, 6-10 jugate, upper leaves similar or } \\
\text { pinnatifid and only } 3-5 \text { jugate; racemes } \\
\text { 30-60-flowered, flowers minute. }\end{array}$ \\
\hline Coronopus didymus & $\begin{array}{l}\text { Mar-Jun Dicot } \\
\text { Annual or }\end{array}$ & $\begin{array}{c}\text { Dicot } \\
\text { Annual or }\end{array}$ & $\begin{array}{l}\text { Annual or } \\
\text { Biennial }\end{array}$ & $\begin{array}{l}\text { Diffuse or procumbent; basal and lower leaves rosulate, } \\
\text { pinnatisect, stalked, } 6-10 \text { jugate, upper leaves similar or } \\
\text { pinnatifid and only } 3-5 \text { jugate; racemes } 30-60 \text {-flowered, } \\
\text { flowers minute. }\end{array}$ \\
\hline Cynodon dactylon & Whole year & Monocot & Perennial & $\begin{array}{l}\text { Widely creeping by runners and forming tufts; leaf blades } \\
\text { linear to lanceolate; infl. racemes usually 4-6; } \\
\text { spikelets } 1 \text {-flowered. }\end{array}$ \\
\hline Euphorbia helioscopia & Jan-July & Dicot & Annual & $\begin{array}{l}\text { An erect sparingly pilose to glabrescent bright green fleshy } \\
\text { herb; fruit roundly triobate with deep grooves; seeds ovoid, } \\
\text { strongly reticulate, dark brown. }\end{array}$ \\
\hline Fumaria indica & Mar-Jun & Dicot & Annual & $\begin{array}{l}\text { Small, delicate, much branched, leafy, diffuse herb; leaves } \\
\text { much dissected, 2-3-pinnatisect or decompound; } \\
\text { racemes 6-12 (-15)-flowered. }\end{array}$ \\
\hline Galium aparine. & Mar-Jul & Dicot & Annual & $\begin{array}{l}\text { Climbing herb, reflexed hairs or prickles; leaves 6-8 in a } \\
\text { whorl, linear; inflorescence axillary, } \\
\text { 3-flowered; corolla white. }\end{array}$ \\
\hline Lathyrus aphaca & Feb-Mar & Dicot & Annual & $\begin{array}{l}\text { Trailing or scrambling annual; stipules foliaceous, broadly } \\
\text { ovate, hastate, rest of the leaf reduced to a tendril. Infl. } \\
\text { 1-2-flowered, axillary raceme; corolla fruit 4-6-seeded. }\end{array}$ \\
\hline Lathyrus sativus & Mar-Aug & Dicot & Annual & $\begin{array}{l}\text { herb; stem winged; leaf pinnately compound, leaflets } 2 \text {, } \\
\text { some what linear, upper leaves with mostly } 3 \text {-sect tendrils; } \\
\text { peduncle 1-flowered; corolla red, blue or white; fruit upper } \\
\text { suture broadly winged; 3-5-seeded. }\end{array}$ \\
\hline
\end{tabular}




\section{Continued}

\begin{tabular}{|c|c|c|c|c|}
\hline Lepidium sativum & Apr-Jun & Dicot & Annual & $\begin{array}{l}\text { erect herb; lower leaves pinnatisect or lyrate-pinnate; } \\
\text { racemes branched, each 20-30-flowered; flowers small, } \\
\text { white or pinkish; fruit winged; seed brown. }\end{array}$ \\
\hline Malva parviflora & Mar- & Dicot & Annual & $\begin{array}{l}\text { prostrate herb; leaves orbicular, cordate at base; flowers } \\
\text { axillary usually fascicled, rarely solitary; petals white, } \\
\text { pinkish at the tips; fruit discoid, mericarps (8-)10. }\end{array}$ \\
\hline Medicago polymorpha & Aug-Oct & Dicot & Annual & $\begin{array}{l}\text { somewhat spreading; leaves trifoliate; infl. } 2-8 \text {-flowered } \\
\text { raceme with yellow flowers; fruit with spines hooked in } 2 \\
\text { rows lying almost parallel to the surface of the disc. }\end{array}$ \\
\hline Melilotus alba & Mar-Sept & Dicot & Annual & $\begin{array}{l}\text { An erect herb; leaves, trifoliate; infl.raceme with white } \\
\text { flowers; fruit single seeded pod; seeds orange brown. }\end{array}$ \\
\hline Melilotus indica & Mar-Apr & Dicot & Annual & $\begin{array}{l}\text { Erect annual herb; leaves compound, trifoliate; infl. } \\
\text { a 10-16-flowered raceme with yellow flowers; } \\
\text { fruit single seeded pod; seeds orange brown. }\end{array}$ \\
\hline Phalaris minor & Mar-May & Monocot & Annual & $\begin{array}{c}\text { Culms } 20 \text { - } 100 \mathrm{~cm} \text { high, profusely branched tillers at the } \\
\text { base; leaves linear, sheathing; inflorescence terminal } \\
\text { spike, ovate-oblong. }\end{array}$ \\
\hline Polypogon monspeliensis 1 & Mar-Jul & Monocot & Annual & $\begin{array}{l}\text { Cculms } 6-80 \mathrm{~cm} \text { high, erect or geniculately ascending. } \\
\text { Panicle narrowly ovate to narrowly oblong, cylindrical or } \\
\text { lobed, very dense and bristly, pale green. }\end{array}$ \\
\hline Polygonum plebejum & $\begin{array}{l}\text { whole } \\
\text { year }\end{array}$ & Dicot & Annual & $\begin{array}{c}\text { Prostrate, densely branched herb. Stem } 1 \text { lineolate, branched } \\
\text { from bases.Leaves linear, Inflorescence axillary, } \\
\text { 3-4-flowered. Flowers sunken between ochrea } \\
\text { or hardly exserted, pink in colour. }\end{array}$ \\
\hline Rumex dentatus & Feb-Sept & Dicot & Annual & $\begin{array}{c}\text { An erect annual herb with large lower leaves a and oblong to } \\
\text { linear upper leaves; flowers in I distinct whorls which are } \\
\text { usually leafy, green; achenes acutely trigonous, } \\
\text { almost winged. }\end{array}$ \\
\hline Saponaria vaccaria & Feb-Apr & Dicot & Annual & $\begin{array}{l}\text { An erect herb; leaves opposite, sessile; inflorescence } \\
\text { dichasial panicle; corolla pink; capsule sub globose. }\end{array}$ \\
\hline Sisymbrio irio & Mar-May & Dicot & Annual & $\begin{array}{c}\text { An erect herb; basal and lower leaves, pinnately lobed with a } \\
\text { hastate terminal lobe; racemes 50-80(-100)-flowered; } \\
\text { yellow; siliqua with ute brown seeds. }\end{array}$ \\
\hline Sonchus asper & Jun-Oct & Dicot & Annual & $\begin{array}{l}\text { erect herb; leaves lobed, margin spiny, basal lobes of the } \\
\text { cauline leaves rounded; infl. head yellow; } \\
\text { achene having papus. }\end{array}$ \\
\hline Spergula arvensis & Mar-Apr & Dicot & Annual & $\begin{array}{l}\text { Stems ascending, leaves in false whorls, linear-subulate; } \\
\text { flowers solitary or in few-flowered cymes; petals white, } \\
\text { as long as or slightly exceeding the sepals. }\end{array}$ \\
\hline Stelleria media & Feb-Apr & Dicot & Annual & $\begin{array}{l}\text { With prostrate to ascending stems; flowers in lax panicles; } \\
\text { petals white, deeply bilobed; capsule splitting by valves } \\
\text { nearly to the base; seeds small, brown. }\end{array}$ \\
\hline Vicia sativa & Mar-Apr & Dicot & Annual & $\begin{array}{c}\text { Climbing or decumbent herb;leaves pinnately compound } \\
\text { with 4-18 linear leaflets per leaf; flower reddish blue; } \\
\text { legume with grayish black seeds. }\end{array}$ \\
\hline
\end{tabular}

\section{Result and Discussion}

Weed flora of the study area is comprised of 32 species including 5 monocots distributed across 29 genera and 15 families ( 2 monocot and 13 dicot). The dominant weeds prevailing in wheat crops were Avena fatua, Chenopodium album, Chenopodium murale, Convolvulus arvensis, Cynodon dactylon, Malva parviflora, Melilotus indica, Medicago denticulata, Phalaris minor and Rumex dentatus. The other reported weeds were of rare occurrence. The detail list of weeds identified in wheat crop in the study area along with their scientific names, families, English names, vernacular names and major diagnostic characters are given in Tables $\mathbf{1}$ and $\mathbf{2}$.

The predominance was shown by Fabaceae, Asteraceae and Poaceae represented by 6, 4 and 4 weed species respectively. Bracicaceae, Caryophyllaceae included three weed species each. Chenopodiaceae and Polygonaceae were represented by two species each.

The remaining families were represented by one weed species each. The relative \% age of family Fabaceae is 


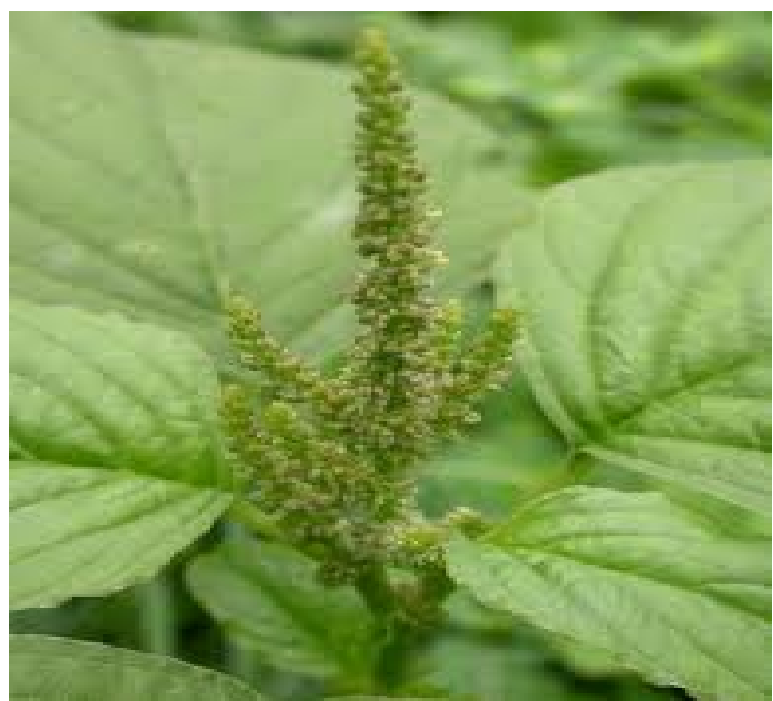

(a)

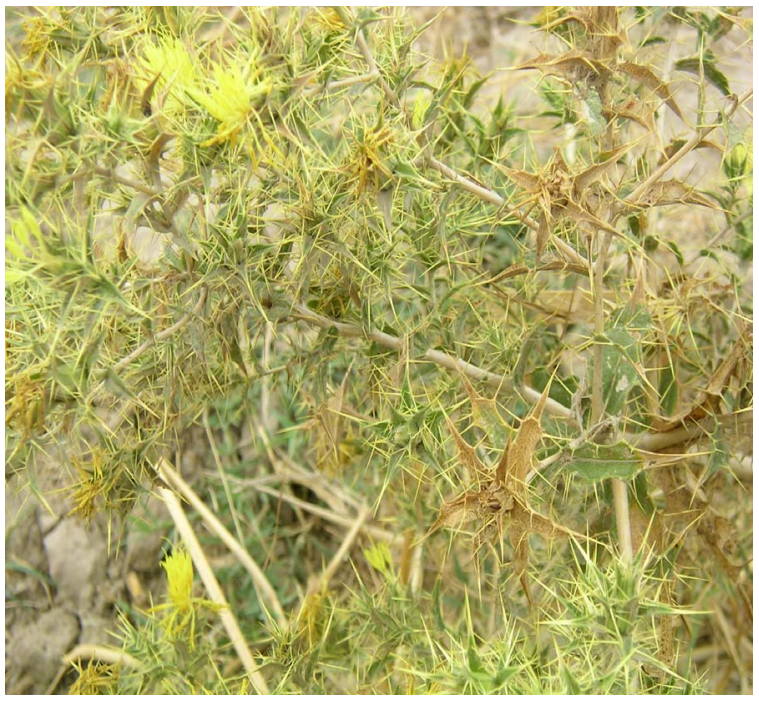

(c)

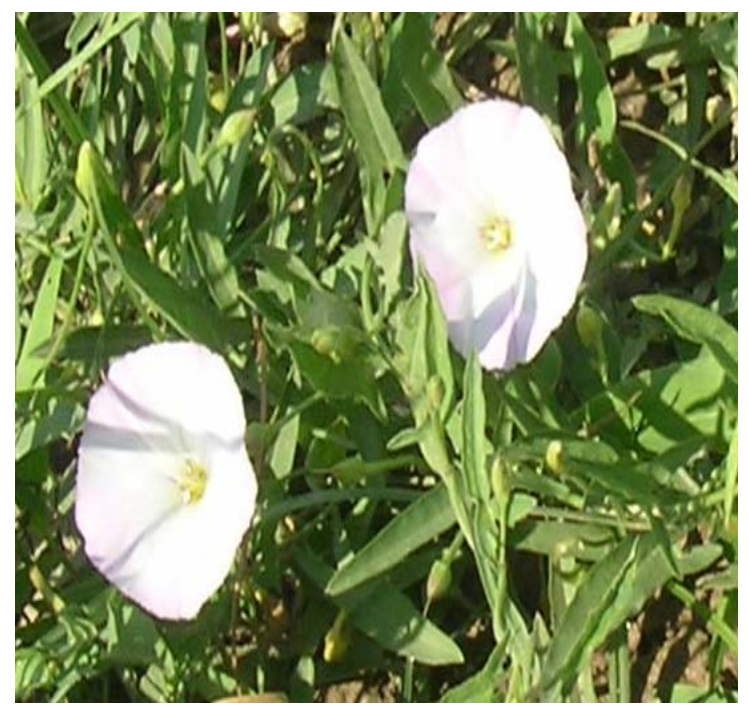

(e)

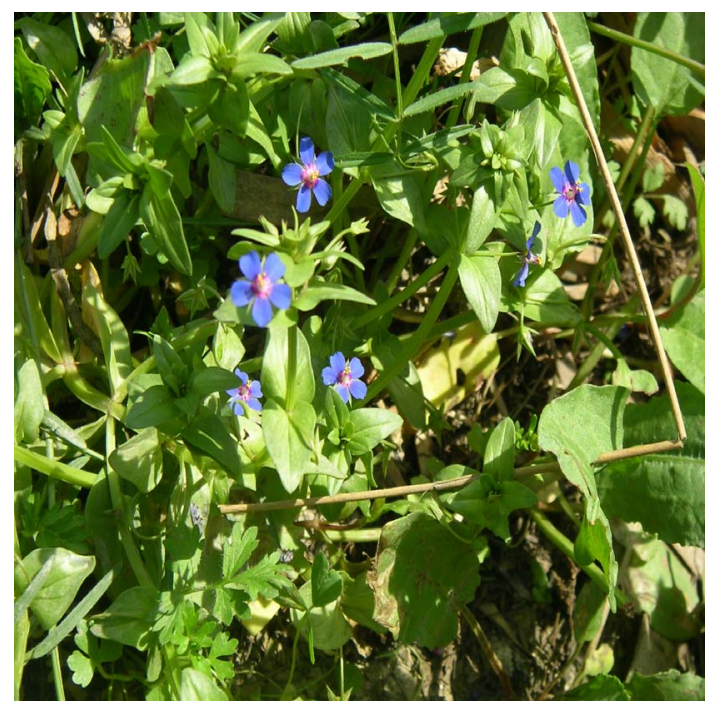

(b)

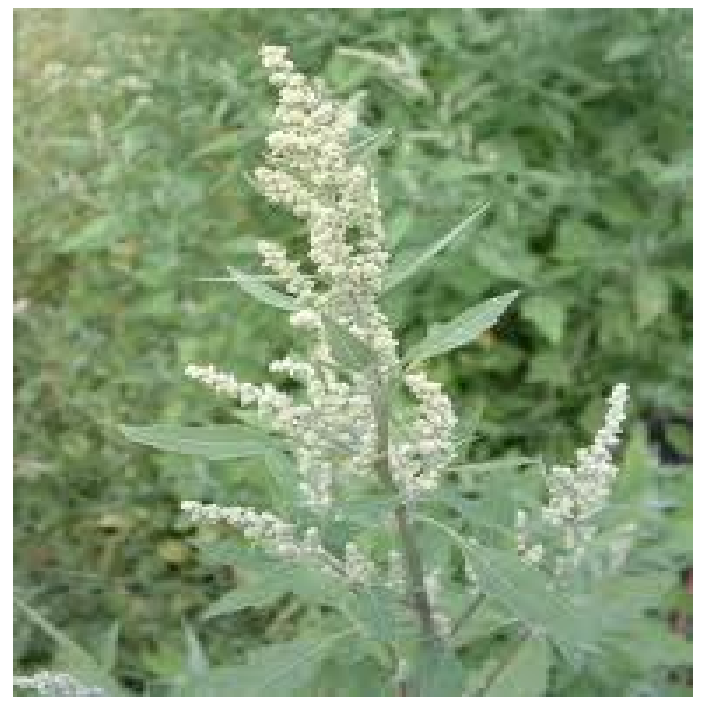

(d)

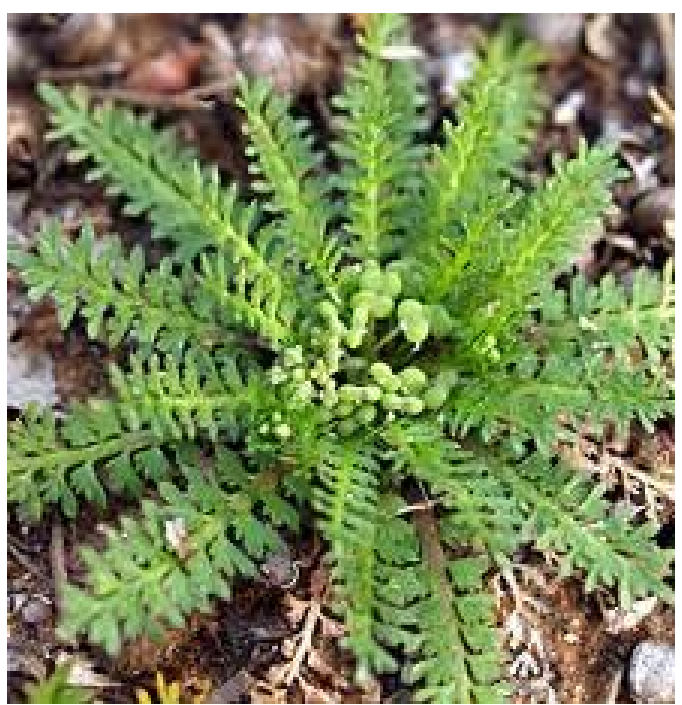

(f) 


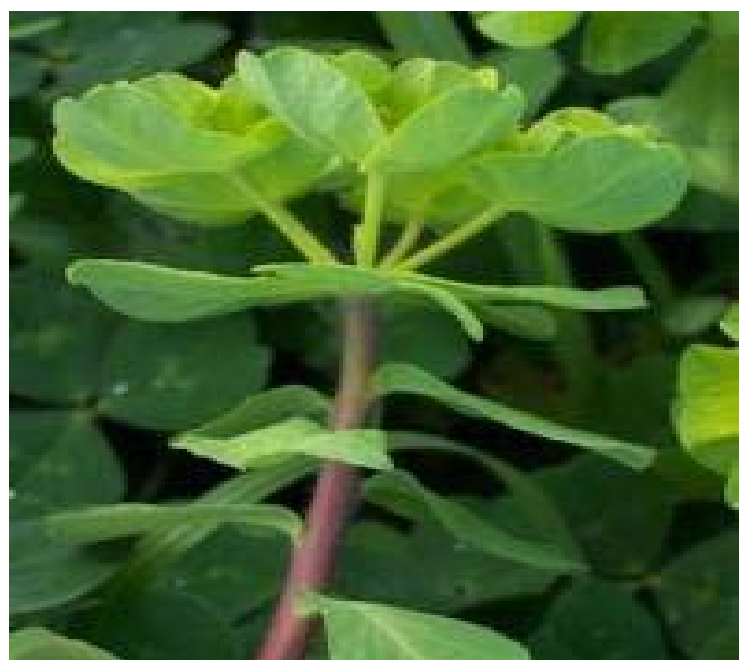

(g)

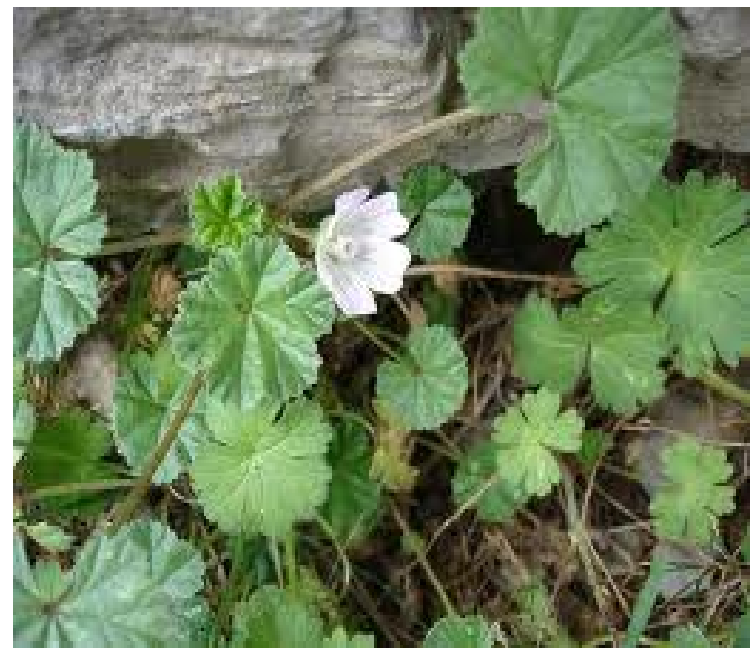

(i)

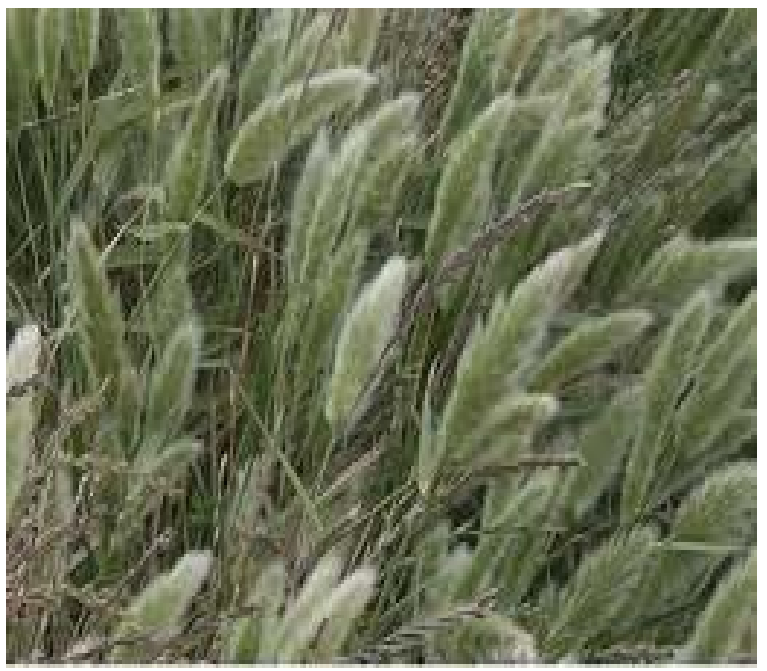

(k)

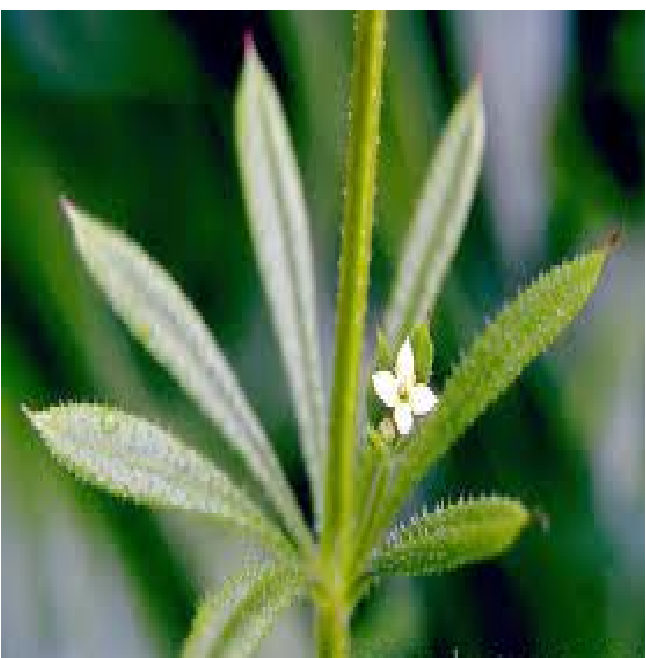

(h)

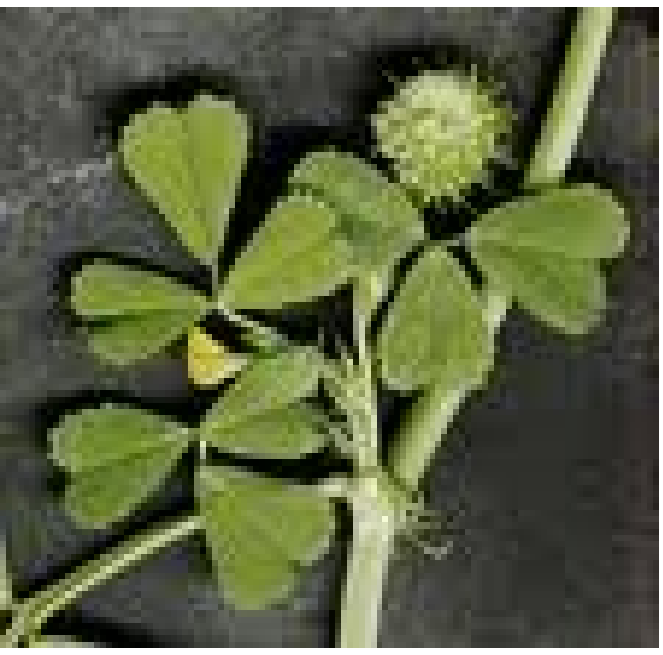

(j)

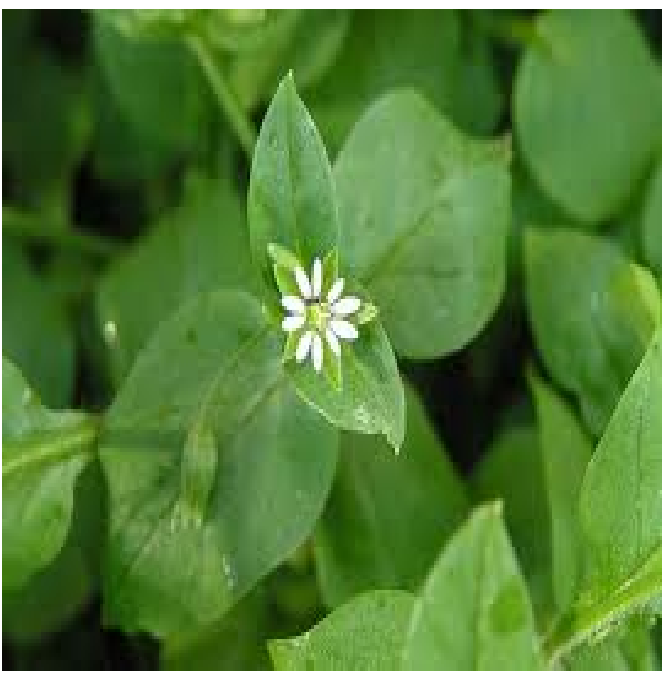

(1)

Figure 2. (a) Amaranthus viriuis L.; (b) Anagalis arvensis L.; (c) Carthamus oxycantha (L.) G. Don; (d) Chenopodium album L.; (e) Convolvulus arvensis L.; (f) Coronopus didymus (L) Smith; (g) Euphorbia helioscopia L.; (h) Gallium aparina L.; (i) Malva parviflora L.; (j) Medicago polymorpha L.; (k) Polypogon monspoliensis (L.) Desf.; (l) Stelleria media (L.) Vill. 
Table 3. Percentage of families of weed plant species in wheat crop in D. I. Khan district.

\begin{tabular}{cccc}
\hline S. $\#$ & Family & No. of species & \% age \\
\hline 1. & Fabaceae & 6 & 18.75 \\
2. & Asteraceae & 4 & 12.50 \\
3. & Poaceae & 4 & 12.50 \\
4. & Brassicaceae & 3 & 08.375 \\
5. & Caryophyllaceae & 3 & 08.375 \\
6. & Chenopodiaceae & 2 & 06.25 \\
7. & Polygonaceae & 2 & 06.25 \\
8. & Amaranthaceae & 1 & 03.12 \\
9. & Asphodeliaceae & 1 & 03.125 \\
10. & Convolvulaceae & 1 & 03.125 \\
11. & Euphorbiaceae & 1 & 03.125 \\
12. & Fumariaceae & 1 & 03.125 \\
13. & Malvaceae & 1 & 03.125 \\
14. & Primulaceae & 1 & 03.125 \\
15. & Rubiaceae & 1 & 03.125 \\
\hline
\end{tabular}

$18.8 \%$, Asteraceae and Poaceae $12.5 \%$, Brassicaceae and Caryophyllaceae $8.4 \%$, Chenopodiaceae and Polygonaceae $6.3 \%$ and of other families is $3.1 \%$ each (Table 3 , Figure 3).

The data on relative weed density at different locations in D. I. Khan District revealed that P. minor Retz. had the maximum infestation of $37.8 \%$ and $46.4 \%$ during 2008-2009 and 2009-2010, respectively (Table 4). $R$. dentatus was the next major weed with $26.8 \%$ and $33.4 \%$ during 2008-2009 and 2009-2010, respectively. There was significant effect of locations in each year as well as mean over years on $R$. dentatus. There was more infestation of $R$. dantatus at Gomal University particularly in 2009-2010 growing season compared to other locations. However, relative weed densities for all other weed species were statistically identical in individual years as well as mean over years.

The weeds control is the basic requirement and the major component of crop management in the production system [8].

The cultivated crops are infested with different weed species in various countries of the world. Moreover, ecotypes occurring in different regions may differ in response to control method. Thus each weed-crop-environmental complex requires special technology. The problem of weed control, especially in the canal irrigated area, is very intricate. In fact, canal water is the principle source of dissemination of weed seeds. A constant effort is needed to keep the weed population under control.
Many methods of weed control and weed eradication have been devised. However, the method to be employed varies with the weed [20]. The following methods are generally used in Dera Ismail Khan District.

1) Dab: It is a local term which means that after presowing irrigation (rauni) when the soil comes into workable condition, it is ploughed and planked by a heavy sohaga. For a period of 7 to 10 days, the soil is left as it is so that weed seeds may germinate, which are destroyed while preparing the soil for wheat sowing.

2) Hoeing and Weeding: Mechanical hoeing and weeding is a good measure for eradication of weeds during early growth period or during seedling. However, these methods are time consuming and laborious. On large scale these cannot be practiced. Moreover, hoeing and weeding becomes difficult in standing crop particularly in heavy textured soil whereby weeds cannot be uprooted but they are rather cut at the ground surface. Weeds regenerate their growth more vigorously if injured at seedling stage. While doing hoeing and weeding in the standing crops roots of the wheat crop are also damaged. It is difficult to differentiate between some of the weeds such as Phalaris minor and Avena fatua and wheat crop at early vegetative stage while doing weeding [6].

3) Tillage: Tillage is also an effective way to control annual as well as perennial weeds [20]. During primary tillage, the weeds present in the field are uprooted and buried deep in the soil before sowing crop and the weeds germinated after sowing are controlled by inter tillage 


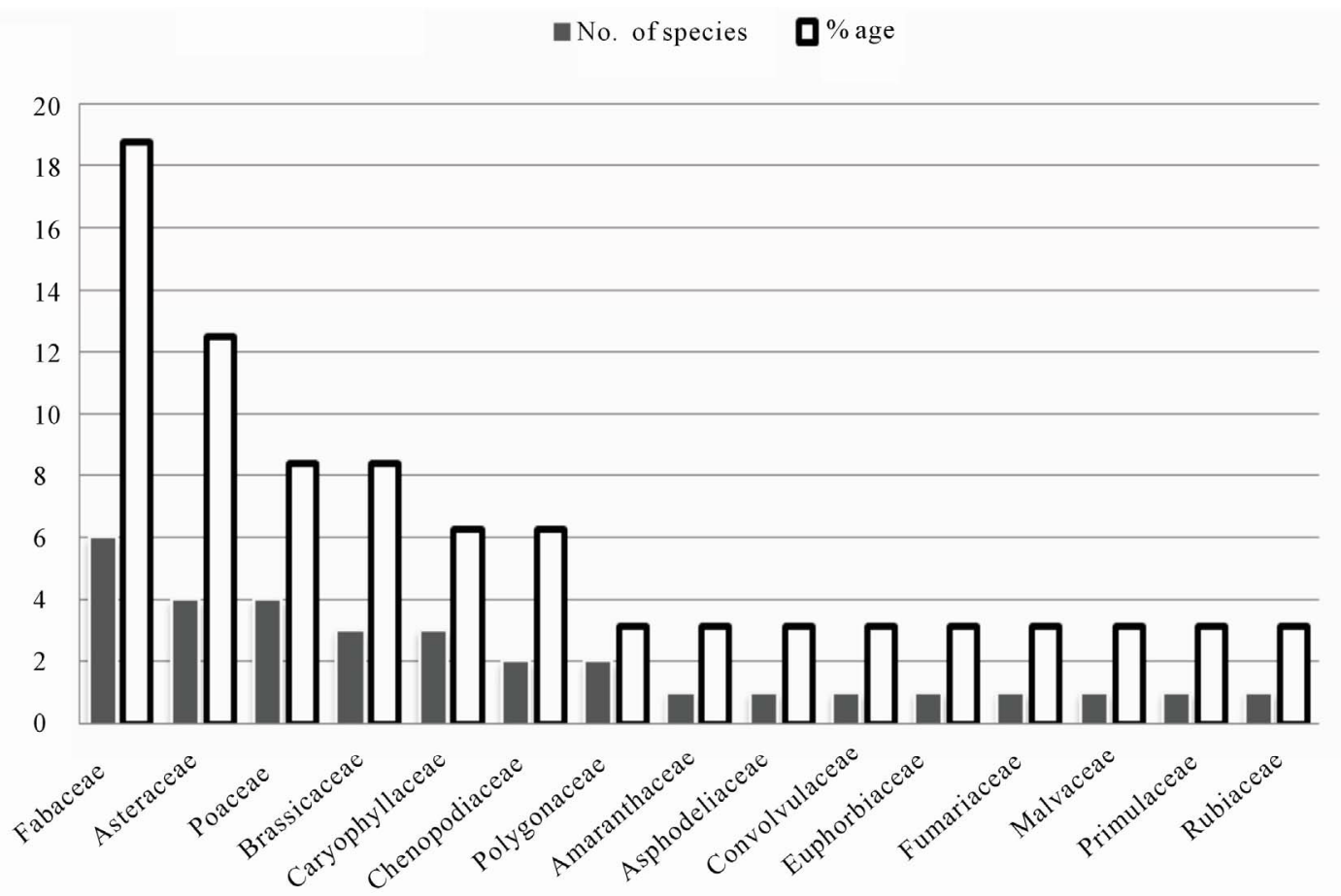

Figure 3. Graph showing \% age of plant families in the weed flora of wheat crop in D. I. Khan district.

Table 4. Relative weed density (\%) at different locations in D. I. Khan district.

\begin{tabular}{|c|c|c|c|c|}
\hline Weed species & Location & 2008-2009 & 2009-2010 & Mean \\
\hline \multirow[t]{4}{*}{ P. minor } & Gomal University & 34.4 & 42.8 & 38.6 \\
\hline & Ratta Kulachi & 44.2 & 45.2 & 44.7 \\
\hline & Paharpur & 34.8 & 51.2 & 43.0 \\
\hline & Mean & 37.8 & 46.4 & \\
\hline \multirow[t]{4}{*}{ R.. dentatus } & Gomal University & $25.8^{\mathrm{b}}$ & $43.5^{\mathrm{a}}$ & $34.7^{\mathrm{a}}$ \\
\hline & Ratta Kulachi & $24.6^{\mathrm{b}}$ & $25.9^{\mathrm{b}}$ & $25.3^{\mathrm{b}}$ \\
\hline & Paharpur & $30.0^{\mathrm{b}}$ & $30.8^{\mathrm{b}}$ & $30.4^{\mathrm{ab}}$ \\
\hline & Mean & 26.8 & 33.4 & \\
\hline \multirow[t]{4}{*}{ M. denticulata } & Gomal University & 25.8 & 10.8 & 18.3 \\
\hline & Ratta Kulachi & 19.0 & 20.1 & 19.5 \\
\hline & Paharpur & 23.4 & 11.8 & 17.6 \\
\hline & Mean & 22.8 & 14.2 & \\
\hline \multirow[t]{4}{*}{ M. indica } & Gomal University & 10.8 & 3.9 & 7.4 \\
\hline & Ratta Kulachi & 11.7 & 5.1 & 8.4 \\
\hline & Paharpur & 8.9 & 5.8 & 7.3 \\
\hline & Mean & $10.4^{\mathrm{a}}$ & $4.9^{\mathrm{b}}$ & \\
\hline \multirow[t]{4}{*}{ C. album } & Gomal University & 6.5 & 3.3 & 4.9 \\
\hline & Ratta Kulachi & 3.5 & 3.5 & 3.5 \\
\hline & Paharpur & 5.7 & 4.8 & 5.2 \\
\hline & Mean & 5.3 & 3.8 & \\
\hline
\end{tabular}

Data in each category followed by same letter (or no letter) do not differ significantly at $5 \%$ level of probability. 
operations in wider row crops [6]. However, this method is not economical due to recent rise in fuel prices. Excessive tillage practices also affect aggregate stability ad degrade soil structure. Zero tillage and reduced tillage technology are the best alternative to conventional tillage. Zero tillage in combination with broad spectrum herbicide is resource conserving and the most effective and economical weed management strategy in Dera Ismail Khan District [21].

4) Bar Harrowing: This is another method of weed eradication. It is used after the application of first or second irrigation and many growing weeds are eradicated. The operation becomes easier when the crop is cultivated in rows.

5) Crop Rotation: Crop rotation is one of the best and effective method for controlling weeds in crops and inclusion of legumes and a fallow in the rotation may enhance soil fertility and allow the natural suppression of weeds. Some weeds are associated with certain crops and changing the crop sequence, disturb the normal life cycle of these weeds. In wheat crop, the problem of weeds especially Phalaris minor and wild oats is increasing rapidly. The well planned crop rotation can effectively help in the control of these weeds. If in a field wheat is grown continuously for 3 years, weed population is increased tremendously. Therefore, in such fields after every three years of wheat cultivation, berseem crop should be cultivated. The cultivation of berseem will add nutrients to the soil in addition to controlling weeds via berseem cuttings [6].

6) Chemical Control: It is the most effective, time saving and economical way of weed control. The weeds especially Avena fatua and phalaris minor are very difficult for the farmers to identify due to their resemblance with the wheat plants in early stages. Keeping the importance of these circumstances in view, it is necessary to select the suitable chemical capable of controlling weeds effectively and economically in wheat crop. There are many kinds of chemicals which are used for controlling the weeds. These chemicals are called as herbicides. The herbicides are most effective in controlling annual as well as perennial weeds. However, it is essential to select an appropriate kind of chemical and to use it at a specified rate, otherwise they may damage the crop [6]. For example, Affinity 50 WDG (carfentrazone ethyle ester + isoproturon) at the rate of $2 \mathrm{~kg} \cdot \mathrm{ha}^{-1}$ is the most effective broad spectrum herbicide controlling almost all species of weeds in wheat, however application of higher dose than the recommended one may cause crop injury [21]. While spraying chemicals, it should be kept in mind that the chemicals not only destroy the weeds but also mix with air, water, and land causing environmental hazards [6]. The fate of these chemicals may appear in residual toxicity to soil microbes and crops when they take up these chemicals in excess. However, if herbicides are sprayed as per recommendations of the manufacturer their residual effects can be kept to the minimum [20]. Eradication of weeds through chemicals is considered suitable for more area during short period of time [6].

\section{REFERENCES}

[1] L. R. Dangwal1, A. Singh, T. Singh, A. Sharma and C. Sharma, "Common Weeds of Rabi (Winter) Crops of Tehsil Nowshera, District Rajouri (Jammu \& Kashmir), India," Pakistan Journal of Weed Science Research, Vol. 16, No. 1, 2010, pp. 39-45.

[2] M. N. Chaudhri, "Weeds and their identification," Identification and Control of Weeds Manual, National Training Course, Pakistan Agriculture Research Council, Islamabad, 1992, p. 14.

[3] S. K. Marwat, M. A. Khan, M. Ahmad, M. Zafar, F. Ahmad and A. Nazir, "Taxonomic Studies of Nodulated Leguminous Weeds from the Flora of North Western Part (Dera Ismail Khan) of Pakistan," African Journal of Biotechnology, Vol. 8, No. 10, 2009, pp. 2163-2168.

[4] T. Z. Mahmood and S. A. Niaz, "Weeds in Cropped Land at Islamabad," NARC, Identification and Control of Weeds Manual, National Training Course, Pakistan Agriculture Research Council, Islamabad, 1992. p. 79.

[5] F. Hussain, A. Murad and M. J. Durrani, "Weed Commuities in the Wheat Fields of Mastuj, District Chitral, Pakistan," Pakistan Journal Weed Science Research, Vol. 10, No. 3-4, 2004, pp. 101-108.

[6] R. Ahmad and A. S. Shaikh, "Common Weeds of Wheat and Their Control," Pakistan Journal of Water Resources, Vol. 7, No. 1, 2003, pp. 73-76.

[7] G. Hassan, B. Faiz, K. B. Marwat and M. Khan, "Effects of Planting Methods and Tank Mixed Herbicides on Controlling Grassy and Broad Leaf Weeds and Their Effects on Wheat cv Fakhr-e-Sarhad," Pakistan Journal of Weed Science Research, Vol. 9, No. 1-2, 2003, pp. 1-11.

[8] Z. Hanif, S. A. Khan, K. B. Marwat, I. A. Khan and Ikramullah, "Importance of Weeds of Wheat Crop of Malakandher Farm, NWFP Agricultural University, Peshawar," Pakistan Journal of Weed Science Research, Vol. 10, No. 3-4, 2003, pp. 109-112.

[9] A. F. Hussain and Z. H. Malik, "Distribution and Population of Weeds in the Wheat Fields of Mayar-Jamdool, District Dir," Scientific Khyber, Vol. 6, No. 1, 1993, pp. 43-57.

[10] G. S. Jakhar, A. Q. Mahar, S. A. Abro and R. Qureshi, "Weed Communities of Wheat Crop under Diverse Edaphography of District Khairpur," Pakistan Journal of Botany, Vol. 37, No. 3, 2005, pp. 709-714.

[11] S. Mohammad, T. A. Cheema, Z. Bashir and R. Mehmood, "Analytical Characteristics of Weeds of Wheat Crop of Tehsil Gojra, Toba Tek Singh," Pakistan Journal of Plant Sciences, Vol. 11, No. 1, 2005, pp. 57-60.

[12] A. Naveed and F. Hussain, "Weeds of Wheat Fields of Village Gambar, District SWAT, Pakistan," Pakistan Journal of Plant Sciences, Vol. 13, No. 1, 2007, pp. 31-35. 
[13] R. Qureshi, A. Waheed and M. Arshad, "Weed Communities of Wheat Crop in District Toba Tek Singh, Pakistan," Pakistan Journal of Botany, Vol. 41, No. 1, 2009, pp. 239-245.

[14] R. U. Khan, "Facts about AZRI," Pakistan Agricultural Research Council, Zone Research Institute Ratta Kulachi, D. I. Khan, 2003, pp. 2-4.

[15] Anonymous, "District Census Report of Dera Ismail Khan," Census Publication No. 50. Population Census, Organization Statistic Division Government of Pakistan, Islamabad, 1998, pp. 1-2.

[16] R. G. D. Steel and J. H. Torrie, "Principles and Procedures of Statistics," McGraw Hill Book Co. Inc., New York, 1980, p. 97.

[17] M. A. Quraishi and S. A. Khan, “An Illustrated Flora of Peshawar District and Agency, Vol. 1 (Ranunculaceae-
Moringaceae)," Pakistan Forest Instirure Peshawar, 1972 , pp. 6-119.

[18] E. Nasir and S. I. Ali, "Flora of Pakistan," National Herbarium, NARC, Islamabad, Department of Botany, University of Karachi, Karachi, (Fascicles), 1972-1994.

[19] S. I. Ali and M. Qaiser, "Flora of Pakistan. (Fascicles)," Department of Botany, University of Karachi, Karachi, 1995-2007.

[20] S. A. Saeed, "Weed Spectra and Their Effect on Production of Wheat and Cotton," 1992, pp. 46-52.

[21] K. Usman, S. K. Khalil, A. Z. Khan, I. H. Khalil, M. A. Khan and Amanullah, "Tillage and Herbicides Impact on Weed Control and Wheat Yield under Rice-Wheat Cropping System in Northwestern Pakistan," Soil \& Tillage Research, Vol. 110, No. 1, 2010, pp. 101-107. doi:10.1016/j.still.2010.07.009 